W. P. Schimper in the work before cited places it in Lepidodendron as a characteristic plant "đes formations houllières inférieures (grauwacke culm) correspondant au calcaire carbonifère." It is therefore evidently more characteristic of the Lowest Carboniferous than of the coal measures ; the older of these formations being considered by Sir Charles Lyell " as equivalents of the Lower Carboniferous, and were even formerly referred to the Devonian group."

I believe enough has now been said to show the part I took in misleading this eminent Professor, and I will leave those interested to judge between the merits of Mr. Carruthers' or Prof. Heers' classification, but in conclusion $I$ must request to be allowed to state that prior to this gentleman's accusation against me, he made me a proposal to help him out of his controversy with Prof. Ifeer, and to "join him in a memoir to describe and figure the valuable materials I had collected;" this I had to decline, because it would not only have interfered with my official duties, but might also have drawn me into a discussion in which I had no interest, besides the probability of its committing me to what may prove to be erroneous opinions.

Dublin, Jan. Io

WM. Hellier Baily

\section{Circumpolar Lands}

IN NATURE of December 28 there is an interesting letter endeavouring to show that the land everywhere about the North Pole down to lat. $57^{\circ}$ is vising. We know less about the South Polar regions, but there are active volcanoes in the Antarctic Continent, and Darwin has shown in his work on volcanic islands that the land and sea-bottom are rising. This appears to be at least a remarkable coincidence.

The earth must be cooling by the escape of the central heat in volcanic eruptions and hot springs, and by slow upward conduction through the strata. As it cools it must contract. Can any mathematical reason be assigned why the contraction should be least in the direction of the polar diameter? This would account for the rising of the land at the poles.

J. J. MURPHY

\section{English Rainfail}

IN NATURE of the IIth inst, your reviewer, "J. K. L." (p. 20I), makes a mistake in stating that the greatest English rainfall takes place at Cockley Bridge, Seathwaite. The greatest fall takes place at the Stye and on the north side of Stye Head, Seathwaite, Borrowdale; whereas the Cockley Bridge named by your reviewer is Seathwaite, Valley of the Duddon, and many miles from the place of greatest fall. He has evidently confounded the two Seathwaites. A reference to Mr. J. G. Symons' annual rainfall returns will show that the Seathwaite named is the one in Borrowdale.

G. V. Vernon

\section{Wanted, a Government Analyst}

I AM a grocer in a small way in a country place, so that I retail almost all that comes under the name of food; and $I$ am very desirous that all should be unadulterated and worth its price, as far as a fair profit will allow. But how am I to ensure this, even supposing I possessed the requisite knowledge and appliances? Time would be wanting to carry out a systematic analysis, and the ordinary "rule of thumb" tests are not a match for the increasing cleverness of "manufacturing chemists." It only remains to send samples to some known food analyst; but here the expense becomes a barrier, when the dealings dependent on it are on a small scale. Is there (or, if not, ought there not to be ?) some Government functionary to whom samples could be sent for testing, at a charge to just cover necessary expenses? After reading a very sad article on "Artificial Milk," in your paper of Dec. 15, I teel emboldened to ask whether, either of yourself or through any of your readers, you could assist me to render practical a feeling I am sure you must sympathise with. For obvious reasons, I ask you to receive in strict confidence the name and address I have given to show the genuine nature of my application.

GROCER

\section{Earthquakes in Celebes}

I WIsin to contribute to the list of earthquakes and eruptions in your journal the following, all of which I have witnessed :-
I 871

May I . Eruption of a volcano on the Island Camiguin, south of the Philippine Islands.

June 13 . Earthquake in Kakas, at the Lake of Tondano in Minahassa, North Celebes, $7 \frac{1}{2}$ P.M. This shock. was at the same time felt throughout Minahassa.

July i5 . Earthquake at Gorontalo, North Celebes, Bay of Tomini, I2 $\frac{1}{2}$ P.M. and $10 \frac{1}{2}$ P.M.

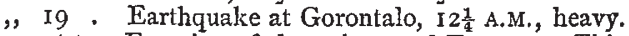

August 7. Eruption of the volcano of Ternate. This exuption had not ended August 23. Most of the inbabitants of Ternate ran away. Stones and ashes were thrown as far as Halmaheira.

,, I9. Earthquale at Gorontalo, 5 A.M.

"25. Seaquake at Gorontalo, 3 P.M.

", 3r. Earthquake at Gorontalo, I P.M., very strong, vers tically.

In the month of August there were at Gorontalo a series of earthquakes, all of which I did not notice in my diary, some of them very severe, shocks so severe and numerous have not been experienced for years at that place. I do not doubt that they were in connection with the long-continued eruption of the volcano of Ternate in the same month.

Some years ago there was communicated to the Paris Academy, from South America, the fact that permanent magnets lose their magnetism during earthquakes. I will not discuss here the theo. retical point of view of the question. During my whole stay in the northern part of Celebes I have always hung up a magnet, with a maximum: weight attached to it, but never, not even during the severe earthquakes of Gorontalo, has the weight fallen down. I therefore doubt the fact.

Earthquakes are felt throughout the northern part of Celebes, on the coasts of the Bay of Tomini, at the Togian Islands in the Bay of Tomini ; whereas in the southern part of Celebes, for instance at Macassar, earthquakes are scarcely ever felt or only very slight ones. The geological structure of the southern part of Celebes differs entirely from that of the northern.

I enclose a list of earthqualies observed at Gorontalo from I $866-70$ by Mr. Riedel.

List of earthquakes at Gorontalo (N. lat. $0^{\circ} 29^{\prime} 42^{\prime \prime}$, W. long. $\left.23^{\circ} 2^{\prime} 5^{\prime \prime}\right)$ between the year 1866 and 1870 :-

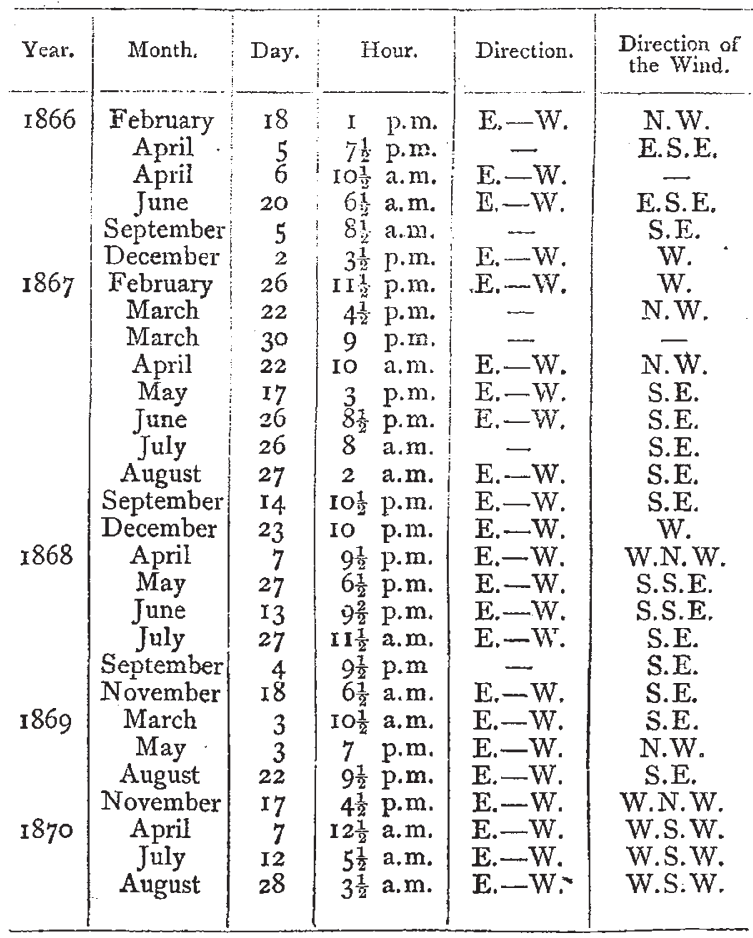

I am now going to the southern parts of the Philippine Islands, and in the following year to New Guinea. A short communication about my travels in Celebes will be found in Petermann's Geographische Mittheilungen.

Macassar, Celebes, Nov, Io, 187 I 